【論文】

UDC : 624. 014. $2: 62-4$
日本建築学全構造系論文報告集第 427 号・1991 年 9 月 Journal of Struct. Constr. Engng, AIJ, No.427, Sep., 1991

\title{
鉄骨構造露出形式柱脚部における基礎コンクリートの 支圧強度に関する実験的研究 \\ EXPERIMENTAL STUDIES ON BEARING STRENGTH OF CONCRETE FOOTINGS AT EXPOSED TYPE OF STEEL COLUMN BASES
}

\author{
九谷和 秀*, 増田貫志** \\ Kazuhide KUTANI and Kanshi MASUDA
}

\begin{abstract}
In this paper, from the results carried out the centrally applied compressive load tests, the eccentrically applied compressive load tests and the lateral load tests under constant axial compressive forces to investigate the bearing strength of footings, conclusions are obtained as follows, as basic data for the ultimate strength design of the exposed type of steel column bases. The ultimate bending strength of footings is able to predict by using an empirical formula of the bearing strength in consideration of the flexural strength and flexural rigidity of base plates and the height of footings. And the ultimate bending strength of footings is able to predict by assuming the distribution of the bearing stress as a second degree parabola or a rectangle.
\end{abstract}

Keywords : column base, base plate, footing, bearing strength, ultimate strength 柱脚, ベースプレート，基礎，支圧強度，終局耐力

1. 序

コンクリートの支圧強度に関しては，これまで多数の 研究成果"が発表されており, 支圧強度には支压面およ び支承面の幾何学的形状・寸法,コンクリート圧縮強度, 載荷板の厚さおよび支圧面の状況, 支承面の状況, 鉛直 および水平荷重の組合せ状況, 補強筋の位置・量, 並び にコンクリートブロックの寸法効果などが関与すること が指摘されている。一般に露出形式柱脚部には, 軸力, 曲げモーメントおよびせん断力が作用し，基礎コンク リートにはそれらの複合された応力が作用していると考 えられ，上記の研究成果を用いて露出形式柱脚の終局曲 げ耐力を予測する場合には，十分な確認実験を行う必要 があろう。

ところで, 露出形式柱脚の基礎コンクリートの支圧強 度に関しては，秋山・黒沢・和国・西村 ${ }^{2}$ 並びに加藤・ 佐藤・鈴木・遠山・中村・坂本 ${ }^{3}$ の研究がある。両者の 共通点は, ベースプレート最外縁と基礎立上がり部最外 縁の距離（へりあき）に着目している点である。前者は 基礎立上がり部之ベースプレートの面積比並びにベース プレートの強度・剛性により2 種類の破壊モード, すな わち基礎立上がり部周辺のコンクリートの剝落並びに
ベースプレート下面の支圧破壊（ベースプレートの底面 積の $1 / 18$ を支生面積と想定）を仮定し，かつこれらの 破壊モ一ドは互いに関連するとし, 終局時の基礎コンク リートの破壊を防ぐための条件式を提案している。後者 は加圧幅（ベースプレートの圧縮側最外縁から中立軸ま での距離に相当）およびへりあきを実験変数とする部分 圧縮試験を行い，支圧強度の実験式を提案している。ま た，若林・南・西村 ${ }^{4}$ は，鉄骨鉄筋コンクリート柱脚部 に関する研究において, 支圧強度の実験式を提案し, 支 圧強度はベースプレート（㴊と仮定）の中立軸比により 変化するとしている。

しかしながら，これらの柱脚に関する支圧強度の実験 式には，支圧強度に影響を及ぼすべースプレートの強 度・剛性および基礎立上がり部の高さの呼価方法並びに せん断力との組合せの問題などが未解決であり, 支王強 度に関する統一された見解を示すには至っていない。

本研究では, 露出形式柱脚部を実物の $1 / 2 \sim 1 / 3$ 程度 の大きさにモデル化し，ベースプレートの強度・剛性並 びに基礎コンクリートおよび無筋コンクリートブロック の形状・法の主な実験変数として中心圧縮試験を行 い, 支圧強度の実験式を求めている。さらに, アンカー

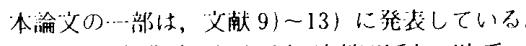

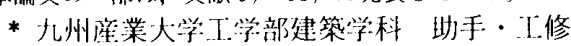

** 九州率業大学:工学部建築举科 教授・1博
Research Assist., Dept. of Architecture, Faculty of Engineering Univ. of Kyushu Sangyo, M. Eng.

Prof., Dept. of Architecture, Faculty of Engineering Univ. of Kyushu Sangyo, Dr. Eng. 
ボルトに引張力を生じない領域における柱脚の終局曲げ 耐力の確認のため, 並びに累加強さ式を適用して柱脚の 終局曲げ耐力を予測する場合の基礎資料として，無筋コ ンクリートブロックの偏心圧縮試験および一定軸力下に おける水平加力試験を行い，中心圧縮力を受ける場合の 支圧強度の実験式を用いて，終局時の基礎コンクリート の曲げモーメントと軸力の相関関係を十分予測可能であ ることを実験的に検証するものである。なお本研究では， せん断力との組合せの問題については言及しない。

\section{2. 基礎コンクリートの支圧強度}

\section{1 試験体}

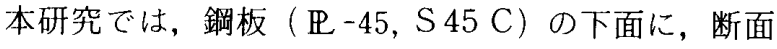
形状を $\square \cdot \mathrm{H} \cdot \bigcirc の 3$ 種類に, 高さを $5 \mathrm{~mm}$ 程度に機械 加工により彫り出した金型状のものを鋼柱の代わりに使 用する。鋼柱断面の寸法は， $\square-150 \times 150 \times 20 ， \square-175$ $\times 175 \times 20, \square-200 \times 200 \times 20, \mathrm{H}-150 \times 150 \times 7 \times 9$, $\mathrm{H}-200 \times 200 \times 8 \times 12$ および $\bigcirc-165 \times 20$ の 6 種類であり, 鋼柱寸法の一覧を Table 1 に示す。

試験体 CC 24 のベースプレートは，400 tf 万能試験機 用の球座圧盤（直径 $300 \mathrm{~mm}$ ) であり，その他の試験体

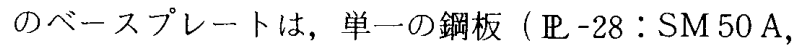
その他の板厚の鋼板：SS 41) である。幅 $300 \mathrm{~mm}$ ，せ い $300 \mathrm{~mm}$ の場合には, 板厚は $75 \mathrm{~mm}, 50 \mathrm{~mm}, 40 \mathrm{~mm}$, $25 \mathrm{~mm}, 19 \mathrm{~mm}, 16 \mathrm{~mm}, 12 \mathrm{~mm}, 9 \mathrm{~mm}$ の 8 種類であり, 幅 $330 \mathrm{~mm}$ ，せい $330 \mathrm{~mm}$ の場合には，板厚は $28 \mathrm{~mm} の$ 1 種類であり, 直径 $300 \mathrm{~mm}$ の場合には, 板厚は 40 $\mathrm{mm}, 25 \mathrm{~mm}, 19 \mathrm{~mm}, 16 \mathrm{~mm}, 12 \mathrm{~mm}$ の 5 種類であり, ベースプレートの寸法の一覧を Table 1 に示す。

コンクリートには，レデーミクストコンクリート（普 通ポルトランドセメント, 海砂, 粗骨材最大寸法 $20 \mathrm{~mm}$ ) を使用しており，基礎コンクリートの形状・寸法を以下 に示す。試験体 CC 1 CC 6, CC 11 CC 13 扰よび CC 15 は，幅 $400 \mathrm{mm，せい} 400 \mathrm{~mm}$, 高さ $600 \mathrm{~mm}$ の 鉄筋コンクリート造基礎柱形（主筋：SD 30，帯筋： SR 24）を有し，基礎柱形の両側に，幅 $250 \mathrm{~mm}$ ，高さ $600 \mathrm{~mm}$ の鉄筋コンクリート造基礎ばり（主筋：SD 30, あばら筋：SR 24）を有している。さらにその基礎柱形 の上に, CC 1 CC 3 には, 幅 $300 \mathrm{~mm}$, せい $300 \mathrm{~mm}$, 高さ $200 \mathrm{~mm}, \mathrm{CC} 4 \sim \mathrm{CC} 6$ には，幅 $350 \mathrm{~mm}$ ，せい 350 $\mathrm{mm}$, 高さ $200 \mathrm{~mm}$ の無筋コンクリート造基礎立上がり 部が後打ちされており，またCC 15 には，幅 $400 \mathrm{mm,}$ せい $400 \mathrm{~mm}$, 高さ $200 \mathrm{~mm}$ の鉄筋コンクリート造基礎 立上がり部が一体打ちされている。なお，CC 1 C C 6 の基礎ばりおよび基礎柱形には，CC 11〜CC 13 上同-... のコンクリートおよび配筋が用いられている。CC 38 CC 40 は, 幅 $400 \mathrm{~mm}$, せい $400 \mathrm{~mm}$, 高さ $600 \mathrm{~mm}$ の 無筋コンクリート造の基礎柱形を有し，基礎柱形の片側
Table 1 Geometric properties of specimens and test results

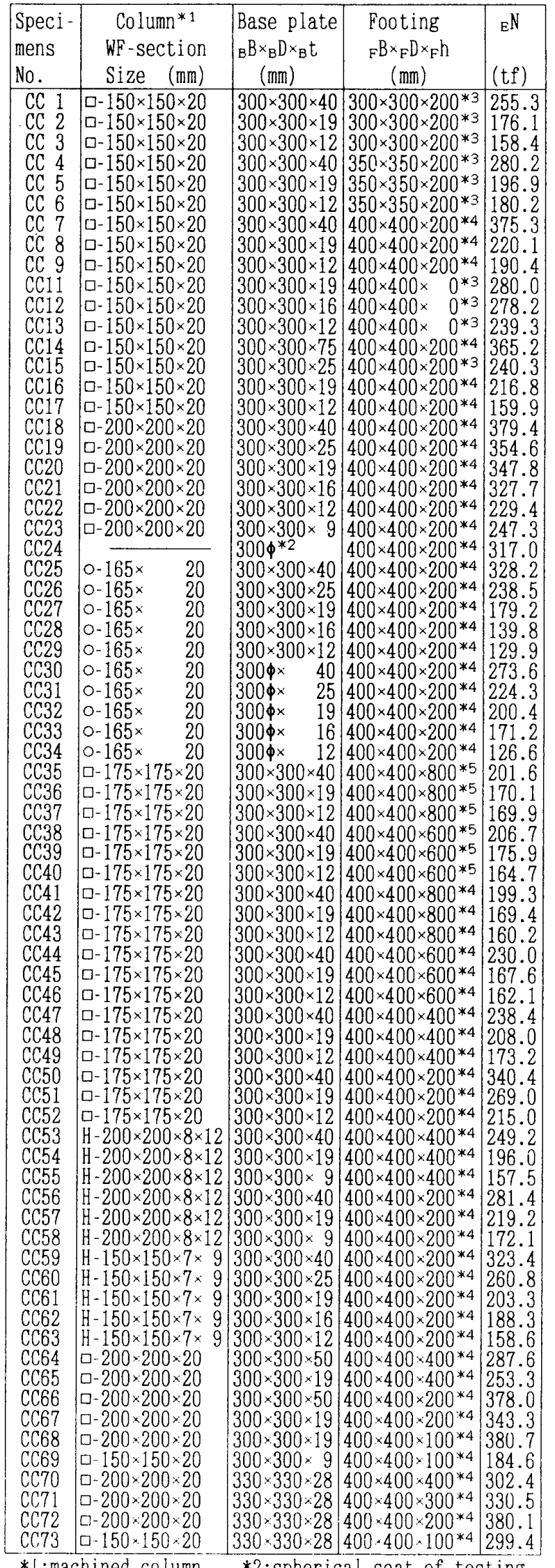

*1:machined column, *2:spherical seat of testing machine, *3:with reinforced concrete beam in boths sides, *4:plain concrete block, *5:with plain concrete beam in one side 
に幅 $250 \mathrm{mm，せい} 600 \mathrm{~mm}$ の無筋コンクリート造基礎 ばりを有している。さらに，CC $35 〜 C C 37$ に，CC 38〜CC 40 亡同形状の基礎柱形の上に，幅 $400 \mathrm{~mm}$ ，せ い $400 \mathrm{~mm}$, 高さ $200 \mathrm{~mm}$ の無筋コンクリート造基礎立 上がり部が一体打ちされている。上記以外の試験体の基 礎コンクリートは, 幅 $400 \mathrm{~mm}$, せい $400 \mathrm{~mm}$ であり, 高さが Table 1 に示すように, $800 \mathrm{~mm}, 600 \mathrm{~mm}, 400 \mathrm{~mm}$, $300 \mathrm{~mm}, 200 \mathrm{~mm}, 100 \mathrm{~mm}$ と変化する無筋コンクリー トブロックである。なお，基礎コンクリートの形状・寸 法の詳紏をTable 1, Fig.1(a)〜（1）に，試験体 CC 1 〜CC 6 並びに CC 11〜CC 13 の配筋図を Fig. 2(a) に， CC 15 の配筋図を Fig. 2(b) に示す。

鋼材およびコンクリートの機械的性質を Table 2 およ び Table 3 に示す。

\section{2 載荷方法}

基礎コンクリートの載荷試験には，400 tf 万能試験機 およびFig. 3 に示すような中心㴼試験装置を用いて いる。なお，試験体のベースプレート下面には，厚さ
$10 \mathrm{~mm}$ 程度の高強度無収縮モルタルが充填されており, モルタルの圧縮強度が $450 \mathrm{kgf} / \mathrm{cm}^{2}$ 程度に達しているこ とを確認した後, 試験機の球座圧盤とベースプレート上 面の間に金型状の鋼柱を置き,載荷試験を開始している。

\section{3 実験結果}

\section{3 .1 破壊状況}

一例として, ベースプレート厚が $40 \mathrm{~mm}, 19 \mathrm{~mm}$ で, 基礎コンクリートの高さが $800 \mathrm{~mm}, 600 \mathrm{~mm}, 400 \mathrm{~mm}$, $200 \mathrm{~mm}$ の試験体の破壊状況を Fig. 4(a)～( h h ) に示す。 支玨ひび割れは，ベースプレート周辺に沿うように，か つそこから基礎コンクリートの側面に向かって放射状に 発生している。ベースプレート厚が小さくなるにつれて それらのひび割れは, ベースプレート外緣から柱フラン ジ直下に移行する傾向を示す。また，基礎の高さが 800 $\mathrm{mm}, 600 \mathrm{~mm}$ と大きい場合には, 基礎コンクリート上 面の各辺中央付近のひび割れ以外は，ほとんよ゙支承面ま で到達していない。

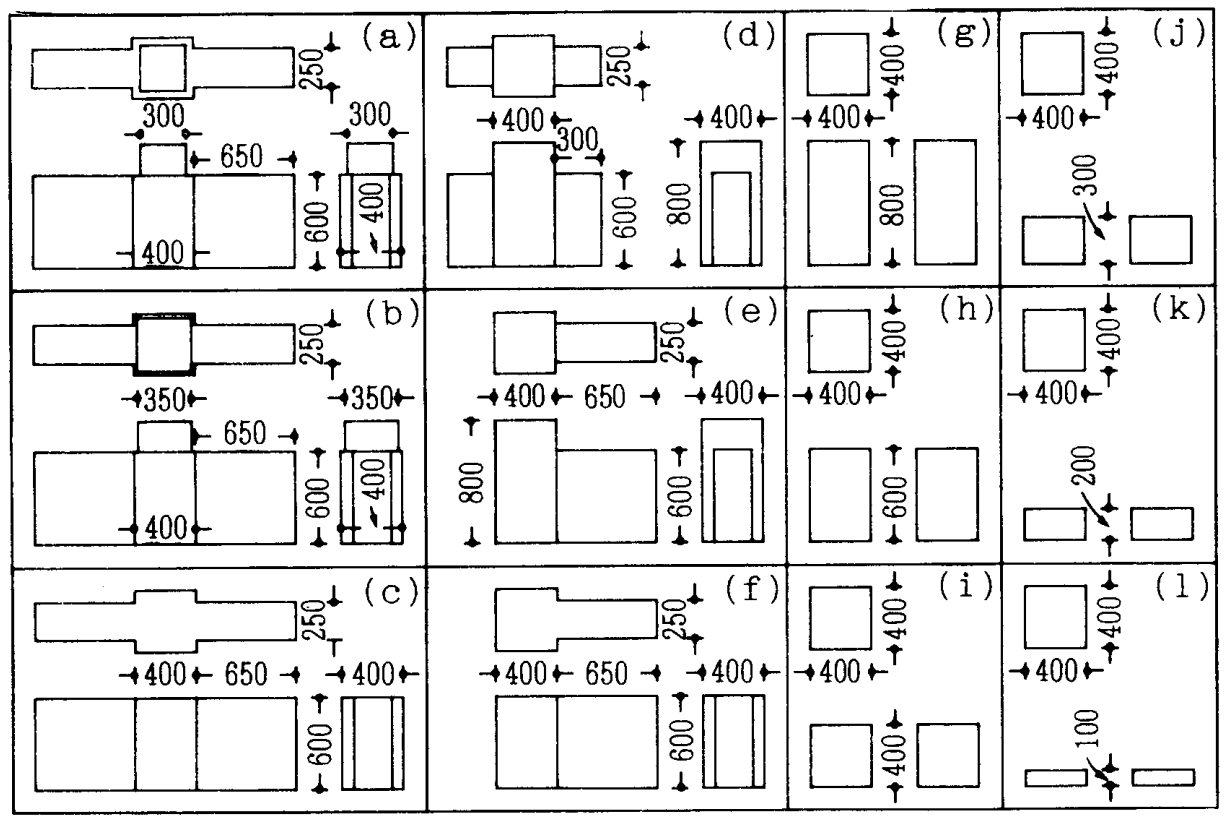

Fig. 1 Details of footings
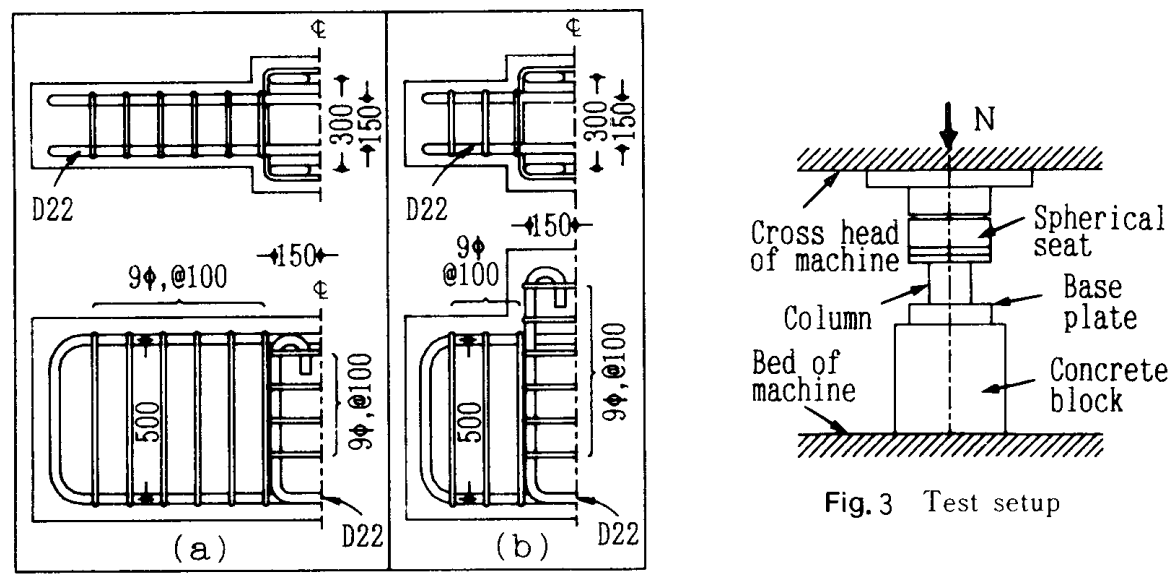

Fig. 3 Test setup
Table 2 Mechanical properties of the steel

\begin{tabular}{|c|c|c|c|c|}
\hline \multicolumn{2}{|c|}{ Materials } & \multirow[t]{2}{*}{$\sigma_{Y}$} & \multirow[t]{2}{*}{$\sigma_{B}$} & \multirow[t]{2}{*}{$\varepsilon_{\mathrm{B}}$} \\
\hline Part & Shape & & & \\
\hline $\begin{array}{l}\text { Base } \\
\text { plate }\end{array}$ & $\begin{array}{l}\mathbb{R}-50 \\
\mathbb{E}-40 \\
\mathbb{P}-28 \\
\mathbb{P}-25 \\
\mathbb{R}-19 \\
\mathbb{R}-16 \\
\mathbb{P}-12 \\
\mathbb{P}-9\end{array}$ & $\begin{array}{l}2.84 \\
2.84 \\
3.31 \\
2.59 \\
2.47 \\
2.48 \\
2.93 \\
3.06 \\
\end{array}$ & $\begin{array}{l}4.73 \\
5.33 \\
5.58 \\
4.27 \\
4.29 \\
4.32 \\
4.63 \\
4.82 \\
\end{array}$ & \begin{tabular}{|l|}
27 \\
28 \\
25 \\
39 \\
35 \\
37 \\
26 \\
28 \\
\end{tabular} \\
\hline Main bar & D-22 & 3.42 & 5.13 & 26 \\
\hline $\begin{array}{l}\text { Hoop and } \\
\text { Stirrup }\end{array}$ & $9 \phi$ & 3.28 & 4.78 & 30 \\
\hline $\begin{array}{l}\sigma_{Y}: Y i e l d \\
\sigma_{B}: \text { Tensi } \\
\varepsilon_{B}: \text { Elonga } \\
\mathbb{R}-50, \mathbb{R}-40 \\
\mathbb{R}-28: \text { SM50 }\end{array}$ & $\begin{array}{l}\text { point } \\
1 \text { stren } \\
\text { ation } \\
0, \mathbb{E}-25 \\
0 A\end{array}$ & $\begin{array}{l}(\mathrm{tf} / \mathrm{c} \\
\text { igth } \\
(\%) \\
(\%)-9: 9\end{array}$ & $\begin{array}{l}\left.\mathrm{m}^{2}\right) \\
\mathrm{tf} / \mathrm{cm}\end{array}$ & \\
\hline
\end{tabular}

Table 3 Mechanical properties of the concrete

\begin{tabular}{|c|c|}
\hline Specimens & $\begin{array}{c}\text { Compressive } \\
\text { strength } \\
\left(\mathrm{kgf} / \mathrm{cm}^{2}\right)\end{array}$ \\
\hline CC 1 CC 9 & 207 \\
CC11 CC13 & 246 \\
CC14 CC17 & 243 \\
CC18 CC24 & 234 \\
CC25 CC34 & 212 \\
CC35 CC52 & 219 \\
CC53 CC58 & 246 \\
CC59 CC63 & 257 \\
CC64 CC69 & 248 \\
CC70 CC73 & 250 \\
\hline
\end{tabular}

Fig. 2 Reinforcement details of footings 


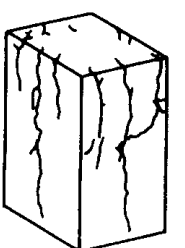

(a) $\mathrm{CC} 41$

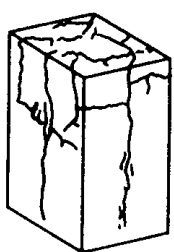

(b) $\mathrm{CC} 42$

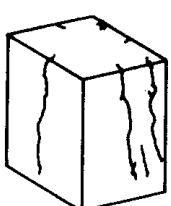

(c) $\mathrm{CC} 44$

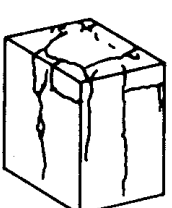

(d) $\mathrm{CC} 45$

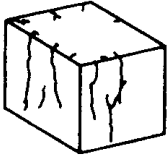

(e) $\quad$ CC47

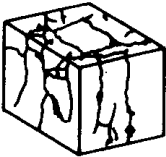

(f) CC48

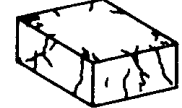

(g) $\quad$ CC50

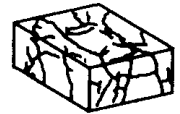

(h) CC51
Fig. 4 Crack patterns of footings

\section{3 .2 実験結果の考察および支生強度の実験式}

コンクリートの支圧強度に関する実験は多く，実験か ら支生強度 $F_{b}$ は，(1) 式の形 ${ }^{11,51,6)}$ で表され，著者ら の実験も実験定数 $\alpha, k$ を求めるものである。

$$
F_{b}=\alpha \cdot F_{c} \cdot(\text { 支承面積 } / \text { 支圧面積 })^{k} \text {. }
$$

$$
\text { ここで }
$$

\section{$\alpha, k:$ 実験定数}

$F_{c}:$ コンクリートの圧縮強度

ベースプレートを剛と仮定すると，基礎コンクリート の支生面積 ${ }_{B} A_{e}$ はベースプレートの底面積 ${ }_{B} B \cdot{ }_{B} D$ とし て表される。また，支承面積 ${ }_{F} A_{e}$ は，基礎立上がり部の 断面積 ${ }_{F} B \cdot{ }_{F} D$ （基礎立上がり部が存在しない場合には, 基礎柱形の断面積）として表されると仮定する。

基礎コンクリートの中心玨縮試験から得られた最大荷 重 ${ }_{E} N$ は, Table 1 に示すとおりであり, 基礎コンクリー 卜の支圧強度 $F_{b}\left(={ }_{E} N /{ }_{B} A_{e}\right)$ とコンクリートのシリン ダ一圧縮強度 $F_{c}$ との比を縦軸に, 支承面積と支生面積 の比を横軸に採ると，実験結果は，Fig. 5 に示すように 表される。なお奏験值は，鋼柱断面・ベースプレート底 面の形状が，それぞれ， $\square \cdot \square の$ 場合にはつ記号，以下 同様に，H・ $\square$ の場合にはD記号，○・○の場合には○ 記号，○・ロの場合には○記号で示されている。また， 相関曲線は，実線で示されており，ベースプレートを㴊 と仮定した場合の基礎コンクリートの支生強度の実験式 は, (2) 式のように得られる。

$$
F_{b}=0.995 F_{c}\left({ }_{F} A_{e} /{ }_{B} A_{e}\right)^{0.226}
$$

図から明らかなように，ベースプレートを剛と仮定し た場合には，相関係数は 0.173 であり，かなり低い相関 を示し，支圧強度を的確に予测することは困難である。

また，Fig.5の点線は，文献 2)，4）に用いられてい る支压強度を表しており, 著者らの実験値との相関はか なり低い。

ベースプレートの強度・剛性および基礎コンクリート の高さが，支圧強度に及ぼす影響を把握するため，以下 のような条件を設ける。

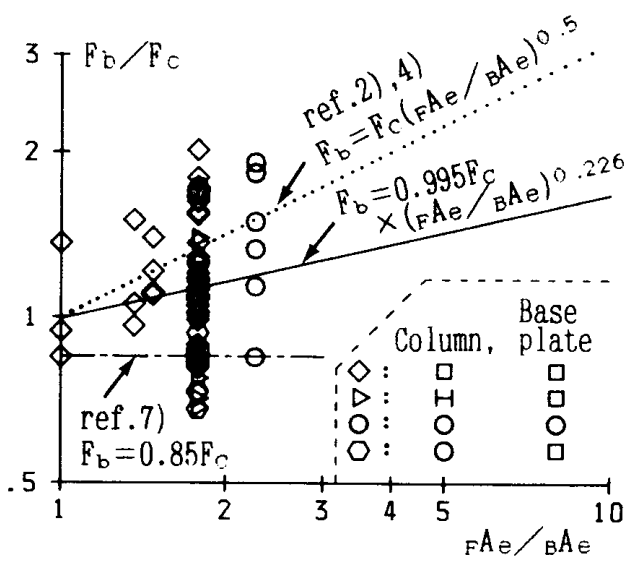

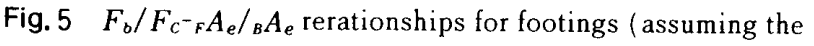
base plate to be rigid body)

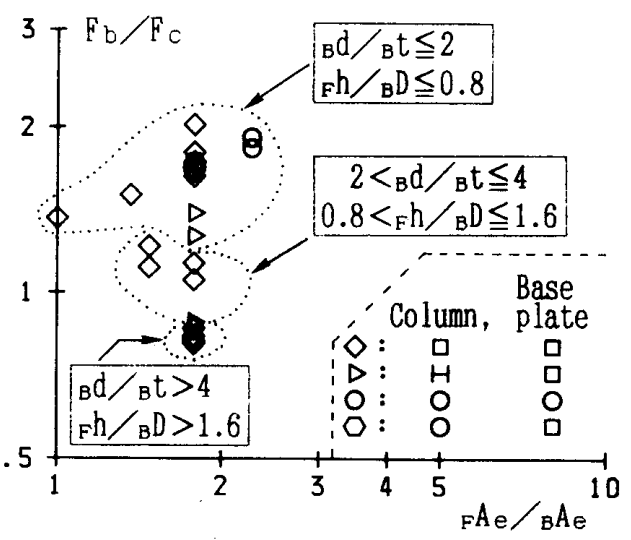

Fig. $6 F_{b} / F_{C^{-}}{ }_{F} A_{e} /{ }_{B} A_{e}$ rerationships for footings (graph showing the variation of bearing strength with ${ }_{B} d /{ }_{B} t$ and $\left.{ }_{F} h /{ }_{B} D\right)$

i ）圧縮側における柱フランジ外面からベースプレート 外縁までの距離 ${ }_{B} d$ とベースプレート厚 ${ }_{B} t$ の比を, ベー スプレートの幅厚比 ${ }_{B} d /{ }_{B} t$ とする。

ii）基礎の高さ ${ }_{F} h$ とベースプレートのせい ${ }_{B} D$ との比 を, 基礎コンクリートの高さ径比 ${ }_{F} h /{ }_{B} D$ とする。ここで, ${ }_{F} h$ は, 中柱形式のように基礎柱形の両側に基礎ばりを 有する場合には，基礎立上がり部の高さ，側柱のように 基礎柱形の片側にのみ基礎ばりを有する場合には，基礎 柱形の高さと基礎立上がり部の高さの和とする。

ベースプレートの幅厚比および基礎コンクリートの高 さ径比が，つぎの（3)〜（ 5 ）式を満足する試験体のみ を抽出し, Fig. 6 に示す。

$$
\begin{aligned}
& { }_{B} d /{ }_{B} t \leqq 2 \text { かつ }{ }_{F} h /{ }_{B} D \leqq 0.8 \\
& 2<_{B} d /{ }_{B} t \leqq 4 \text { かつ } 0.8<_{F} h /{ }_{B} D \leqq 1.6 \\
& { }_{B} d /{ }_{B} t>4 \text { かつ }{ }_{F} h /{ }_{B} D>1.6
\end{aligned}
$$

ここで

本研究に用いた試験体は, ( 3 )式を満足する範囲では, 相対的に強度・剛性の大きなベースプレートかつ相対 的に偏平な形状の基礎コンクリートを有しており， (5)式を満足する範井では,それとは逆の状態であり， 
（4）式を満足する範冊では，それらの中間の状態で あるとおおむね考えられる。

図から明らかなように，支厈強度はベースプレートの 幅厚比が大きくなり，かつ基礎コンクリートの高さ径比 が大きくなるにつれて，小さくなる傾向を示している。 ベースプレートの強度・剛性が小さくなると, 曲げ降伏 および曲げ変形のために支圧面積がベースプレートの全 面積より小さくなること，並びに基礎コンクリートと圧 縮試験用のシリンダーでは高さ径比が異なることなど が、このような傾向を示す主因と推察される。

ところで, Fig. 5 の一点鎖線は, 露出柱脚の終局曲げ 耐力算定用のコンクリートの支圧強度”であり，(6) 式を提示している。

$$
F_{b}=0.85 F_{c}
$$

ここで

立上がり基礎（本研究では，基礎柱形と基礎立上がり 部に区別している）の寸法は，ベースプレートサイズ の 1.15 倍以上を目安とすればよい（CC 1 C C 3 を 除く試験体は，この条件を満足する)。

上記の式から予測される支圧強度は，支圧面積をべー スプレートの底面積と仮定して得られる場合の本研究の 実験結果の下限值におおむ租当している。したがって, ベースプレートの幅厚比が小さくなり，かつ基礎コンク リートの高さ径比が小さくなるにつれて不経済な設計に なることが予想される。

支圧強度に及ぼすべースプレートの強度・剛性の影響 を実験的に評価するため，文献 1)，8）に準じて，鋼柱 底面から $\theta$ の角度で引かれた範井内のベースプレート のみが，一様に基礎コンクリートを支玌していると仮定 する。すなわち，鋼柱に角形鋼管・円形鋼管・H形鋼 を用いる場合の支圧面積 ${ }_{B} A_{e}$ は，それぞれの順に， Fig. 7(a) （c）に斜線で示す面積（黒塗りの鋼柱断面 積も含む) として近似されるとする。例えば，鋼柱断面 が箱形,ベースプレートが長方形の単一鋼板の場合には, 支圧面積は（7）式のように表される。

$$
{ }_{B} A_{e}={ }_{B} B_{O} \cdot{ }_{B} D_{O}-{ }_{B} B_{I} \cdot{ }_{B} D_{I} \cdot
$$

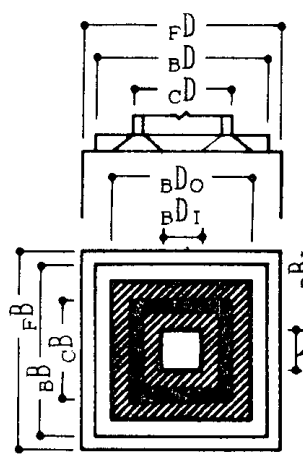

(a)

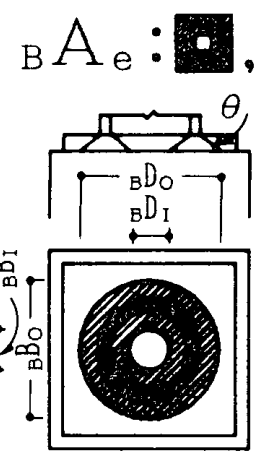

(b)

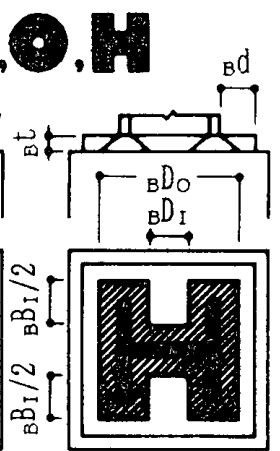

(c)
Fig. 7 Bearing areas of footings
ここで

$$
\begin{aligned}
& { }_{B} B_{O}={ }_{C} B+2{ }_{B} t \cdot \cot \theta \\
& { }_{B} D_{O}={ }_{C} D+2{ }_{B} t \cdot \cot \theta \\
& { }_{B} B_{I}={ }_{C} B-2{ }_{B} t \cdot \cot \theta-2{ }_{C} t \\
& { }_{B} D_{I}={ }_{C} D-22_{B} t \cdot \cot \theta-2{ }_{C} t \\
& 0 \leqq_{B} B_{I}<{ }_{B} B_{O} \leqq_{B} B \\
& 0 \leqq_{B} D_{I}<{ }_{B} D_{O} \leqq_{B} D
\end{aligned}
$$

${ }_{c} B,{ }_{c} D,{ }_{c} t$ ：鋼柱断面の幅，せい，板厚

${ }_{B} B,{ }_{B} D,{ }_{B} t:$ ベースプレートの幅，せい，板厚

ここでは，文献 1)，8）に準じて， $\theta=45^{\circ}$ と仮定し， 基礎コンクリートの支圧強度 $F_{b}\left(={ }_{E} N /{ }_{B} A_{e}\right)$ とコンク リートのシリンダ一生縮強度 $F_{c}$ の比を縦軸に, 支承面 積と支圧面積の比を横軸に採ると，実験結果は，Fig.8 に示すように表される。なお，実験值は，鋼柱断面の形 状执よ゙ベースプレートの形状に応じて Fig. 5 と同一 の記号で示されている。また，相関曲線は，実線で示さ れており，ベースプレートの強度・風性を考虑した基礎 コンクリートの支圧強度の実験式は，（8）式のように 得られる。

$$
F_{b}=1.39 F_{c}\left({ }_{F} A_{e} /{ }_{B} A_{e}\right)^{0.478}
$$

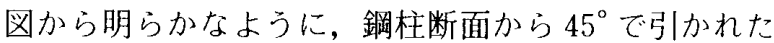
範囲内のベースプレートを支圧面積とする場合には，相 関係数は 0.731 であり，ベースプレートの底面積を支圧 面積とする場合に比べてかなり高い相関を示している。

さらに，支圧強度に及ぼす基礎コンクリートの高さ径 比の影響を実験的に評価するため，基礎コンクリートの 高さを前述の ${ }_{F} h$ とし, 径をFig. 7 に示した支圧面積の せい ${ }_{B} D_{o}$ とし, 基礎コンクリートの圧縮強度 $F_{c}^{\prime}$ を文献 6）に準じて，（9）式のように仮定する。ただし，基礎 コンクリートの高さ径比 ${ }_{F} h{ }_{B} D_{o}$ が 0.5 以下の場合に は，高さ径比を 0.5 とし， $F_{c}^{\prime}$ の上限値を $1.6 F_{c}$ とする。

$$
F_{c}^{\prime}=\left(0.8+0.4{ }_{B} D_{o} /{ }_{F} h\right) F_{c}
$$
ここで

$$
0.8 F_{c} \leqq F_{c}^{\prime} \leqq 1.6 F_{c}
$$

鋼柱底面から $\theta=32.6^{\circ}$ (試行鉷誤により求めている)

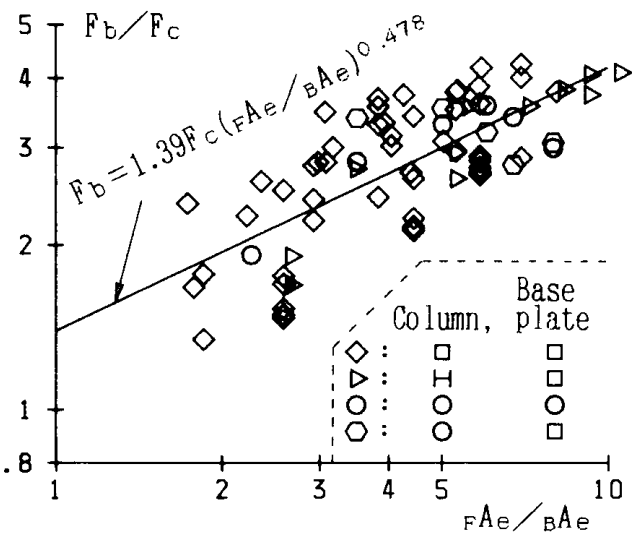

Fig. $8 F_{b} / F_{C^{-}}{ }_{F} A_{e} /{ }_{B} A_{e}$ rerationships for footings (regarding the flexural strength and flexural rigidity of base plates) 
で引かれた範囲内のベースプレートのみが，一様に基礎 コンクリートを支圧していると仮定し，支生強度と圧縮 強度 $F_{c}^{\prime}$ の比を縦軸に, 支承面積と支圧面積の比を横軸 に採ると，実験結果は，Fig.9のように表される。実験 值は，鋼柱断面の形状およびベースプレートの形状に忘 じて Fig. 5 と同一の記号で示されている。また，相関 曲線は，図中に実線で示され，ベースプレートの強度 • 剛性および基礎コンクリートの高さ径比を考慮した支圧 強度の実験式は，(10) 式のように得られる。

$$
F_{b}=0.963 F_{c}^{\prime}\left({ }_{F} A_{e} /{ }_{B} A_{e}\right)^{0.493}
$$

図から明らかなように，鋼柱断面から $32.6^{\circ}$ で引かれ た範囲内のベースプレートを支圧面積とし，かつ基礎コ

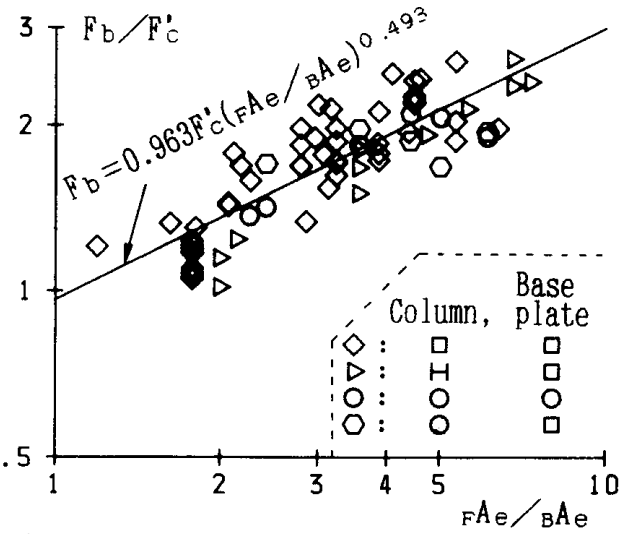

Fig. $9 F_{b} / F_{C}^{\prime}{ }_{F} A_{e} /{ }_{B} A_{e}$ rerationships for footings

Table 4 Geometric properties of specimens and test results

\begin{tabular}{|c|c|c|c|c|c|c|c|}
\hline $\begin{array}{l}\text { Speci- } \\
\text { mens } \\
\text { No. }\end{array}$ & $\begin{array}{c}\text { Column } * 1 \\
{ }_{C} B \times{ }_{C} D \times{ }_{C} t \\
(m m)\end{array}$ & $\begin{array}{c}\text { Base plate } \\
{ }_{B} B \times{ }_{B} D \times{ }_{B} t \\
(\mathrm{~mm})\end{array}$ & $\begin{array}{l}\text { Footing*2 } \\
F B \times_{F} D \times{ }_{F} h \\
(m m)\end{array}$ & \multicolumn{2}{|c|}{$\begin{array}{l}\text { Loading } \\
\text { system } \\
(\mathrm{mm})\end{array}$} & $(t f)$ & $(\mathrm{tf} \cdot \mathrm{m})$ \\
\hline & $150 \times 150 \times 25$ & $330 \times 330 \times 50$ & $400 \times 400 \times 400$ & & $e=100$ & 140.4 & \\
\hline $\begin{array}{l}\text { CE } 2 \\
\text { CE } 3\end{array}$ & $\begin{array}{l}150 \times 150 \times 25 \\
150 \times 150 \times 25\end{array}$ & $\begin{array}{l}330 \times 330 \times 50 \\
330 \times 330 \times 50\end{array}$ & $400 x$ & & $\begin{array}{l}e=100 \\
e=100\end{array}$ & $\begin{array}{l}151.7 \\
169.7\end{array}$ & \\
\hline CE 4 & $150 \times 150 \times 25$ & $330 \times 330 \times 50$ & $400 \times 400 \times 100$ & & $\mathrm{e}=100$ & 190.4 & 19 \\
\hline 6 & $\begin{array}{l}150 \times 150 \times \\
150 \times 150 \times\end{array}$ & $\begin{array}{l}300 \times 300 \times 50 \\
300 \times 300 \times 50\end{array}$ & $\begin{array}{l}400 \times 400 \times 4 \\
400 \times 400 \times 4\end{array}$ & & $\begin{array}{l}\mathrm{e}=25 \\
\mathrm{e}=50\end{array}$ & $\begin{array}{l}230 \\
214\end{array}$ & \\
\hline $\begin{array}{l}7 \\
8\end{array}$ & $\begin{array}{l}150 \times 150 \times 25 \\
150 \times 150 \times 25\end{array}$ & $\begin{array}{l}300 \times 300 \times 50 \\
300 \times 300 \times 50\end{array}$ & $\begin{array}{l}400 \times 400 \times 4 \\
400 \times 400 \times 4\end{array}$ & & $\left|\begin{array}{rr}e & 75 \\
e & =100\end{array}\right|$ & $\begin{array}{l}191.3 \\
132.1\end{array}$ & \\
\hline & $150 \times 150$ & $300 \times 300 \times 50$ & $400 \times 4$ & & $h=1000$ & 55.0 & \\
\hline & $150 \times 150 \times$ & $\times 300 \times 50$ & $400 x$ & & $\begin{array}{l}e- \\
e=\end{array}$ & & \\
\hline & $\begin{array}{l}150 \times 150 \times \\
150 \times 150 \times\end{array}$ & $\begin{array}{l}300 \times 300 \times 50 \\
300 \times 300 \times 50\end{array}$ & $\begin{array}{l}400 \times 4 \\
400 \times 4\end{array}$ & & $\begin{array}{l}e= \\
e=\end{array}$ & & \\
\hline & $150 \times 150 \times$ & $300 \times 300 \times 50$ & $400 \times$ & & $h=1000$ & $\begin{array}{l}114.1 \\
70.0\end{array}$ & \\
\hline & $\begin{array}{l}150 \times 150 \times 25 \\
150 \times 150 \times 25\end{array}$ & $\begin{array}{l}300 \times 300 \times 36 \\
300 \times 300 \times 36\end{array}$ & $\begin{array}{l}400 \times 400 \\
400 \times 400\end{array}$ & & $\begin{array}{l}e=25 \\
e=50\end{array}$ & & \\
\hline & $150 \times 150 \times$ & 300 & & & $\mathrm{e}=$ & & \\
\hline & $150 \times 150$ & $300 \times 300 \times 36$ & $400 \times 400 \times 4$ & & $h=1000$ & 50 & \\
\hline & $\begin{array}{l}150 \times 150 \\
150 \times 150\end{array}$ & $300 \times 3$ & $\begin{array}{l}40 \\
40\end{array}$ & & $\begin{array}{l}e=25 \\
e=50\end{array}$ & & \\
\hline & $150 \times 150 \times 25$ & $300 \times 300 \times 36$ & $400 \times 400 \times 200$ & & $e=75$ & 184.0 & \\
\hline 24 & $\begin{array}{l}150 \times 150 \times 25 \\
150 \times 150 \times 25\end{array}$ & $300 \times 300 x$ & $\begin{array}{l}400 \times 400 \\
400 \times 400\end{array}$ & & $\begin{array}{l}e=100 \\
h=1000\end{array}$ & $\begin{array}{r}131.5 \\
50.0\end{array}$ & 13. \\
\hline 25 & $150 \times 150 \times 25$ & $300 \times 3$ & $400 \times 40$ & & $e=25$ & 190.0 & \\
\hline & $150 \times 150$ & 5 & 00 & & $e=$ & 120.2 & 9. \\
\hline$\Delta \angle S$ & & & & & $\begin{array}{l}e=100 \\
h=1000\end{array}$ & 40.0 & \\
\hline & $150 \times 1$ & $300 \times 300 \times 25$ & $400 \times 400 \times 200$ & & $e=$ & 241.5 & 6.0 \\
\hline & & $00 \times 25$ & & & & & 10. \\
\hline & & & & & & & \\
\hline & & & & & & & \\
\hline
\end{tabular}

$* 1$ :built-up, *2:concrete block, E.C.L.:Eccentrically applied compressive load, O.M.L.:one way monotonous lateral load, e:eccentricity, h:distance between position of lateral load and bottom of base plate
ンクリートの高さ径比に応じた圧縮強度 $F_{c}^{\prime}$ を用いた場 合には，相関係数は 0.850 であり，（2）式および（8) 式に比べてより高い相関を示すことが分かる。

以上に示した実験結果から，(2)，(8)，(10) 式のよ うに 3 種類の支圧強度の実験式が得られたが，ベースプ レートの強度・崳性を考慮し，かつ基礎コンクリートの 高さ径比に応じた圧縮強度を用いて得られた（10）式は， 露出形式柱脚の中心王縮耐力を予測する場合に用いる基 礎コンクリートの支圧強度の実験式として最適であると 考えられる。

\section{3. 基礎コンクリートの終局曲げ耐力}

\section{1 試験体}

鋼柱は，溶接による組立圧縮材であり，断面の寸法は - $150 \times 150 \times 25$ の 1 種類である。

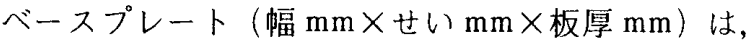
試験体 CE 1 CE 4, CE 5 CE 14, CE 15 CE 24, CE 25 CE 34 の順に, $330 \times 330 \times 50,300 \times 300 \times 50$, $300 \times 300 \times 36,300 \times 300 \times 25$ の 4 種類であり，鋼柱と 突合せ溶接されている。なお，ベースプレートの寸法の 一覽を Table 4 に示す。

基礎コンクリートは，無筋コンクリートブロックであ り，断面（幅 $\mathrm{mm} \times$ せい $\mathrm{mm}$ ）は， $400 \times 400$ であり，高 さは 4 種類あり, CE 1, CE 5 C C 9, CE 15〜CE 19 および CE 25 - CE 29 は $400 \mathrm{~mm}$, CE 2 は $300 \mathrm{~mm}, \mathrm{CE} 3$, CE 10 〜 CE 14, CE 20〜CE 24 および CE 30〜 CE 34 は $200 \mathrm{~mm}, \mathrm{CE} 4$ は $100 \mathrm{~mm}$ であ る。なお，基礎コンクリートの形状・寸法 の詳細を Table 4 およびFig. 10(a)〜(d) に示す。

鋼材およびコンクリートの機械的性質 を，それぞれ，Table 5 およびTable 6 に 示す。また，鋼材は，すべて SS 41 であり， セメントおよび骨材の種類は, 中心圧縮試 験で用いたものと同一である。

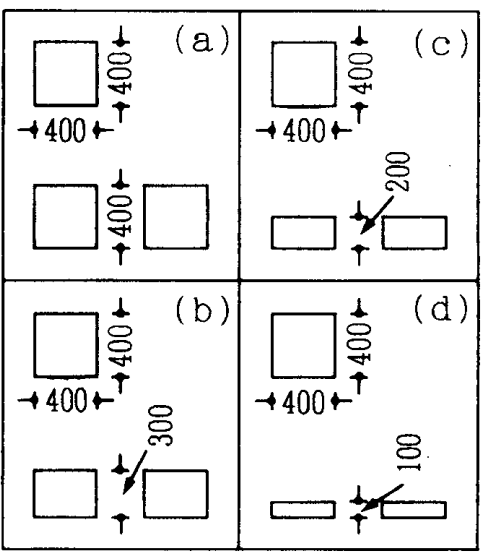

Fig. 10 Details of footings 


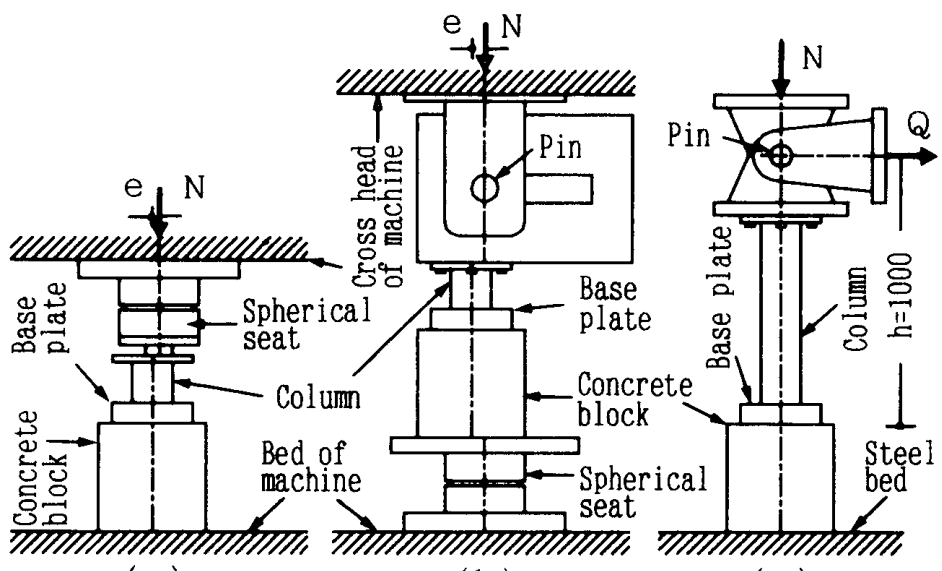

(a) (b)

(c)

Fig. 11 Test setup

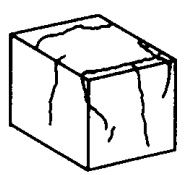

(a) CE 7

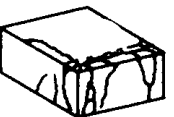

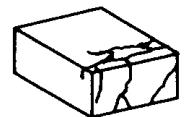

(e) CE22

(f) CE32

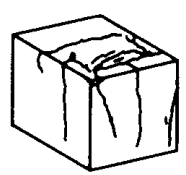

(b) CE17

(c) CE27

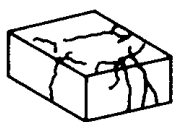

Fig. 12 Crack patterns of footings

Table 6 Mechanical properties of the concrete

Table 5 Mechanical properties of the steel

\begin{tabular}{|l|l|l|l|l|}
\hline \multicolumn{2}{|c|}{ Materials } & OY & $\sigma_{\mathrm{B}}$ & $\varepsilon_{\mathrm{B}}$ \\
\hline Part & Shape & & & \\
\hline Column & $\mathbb{P}-25$ & 2.64 & & \\
\hline Base & $\mathbb{R}-50$ & 2.84 & 4.73 & 27 \\
plate & $\mathbb{R}-36$ & 2.66 & 4.61 & 29 \\
& $\mathbb{R}-25$ & 2.64 & 4.50 & 32 \\
\hline
\end{tabular}

$\sigma_{Y}:$ Yield point $\left(\mathrm{tf} / \mathrm{cm}^{2}\right)$ $\sigma_{B}:$ Tensil strength $\left(t f / \mathrm{cm}^{2}\right)$ $\varepsilon_{\mathrm{B}}:$ Elongation $(\%)$

\begin{tabular}{|l|c|}
\hline Specimens & $\begin{array}{c}\text { Compressive } \\
\text { strength } \\
\left.\text { (kgf/cm }^{2}\right)\end{array}$ \\
\hline CE 1 CE 4 & 250 \\
\hline CE 5 & \\
CE 9 CE10 & 262 \\
CE14 CE27 & \\
CE34 & \\
\hline CE 6 CE 8 & 291 \\
CE11 CE13 \\
CE18, CE23 \\
CE28,CE33
\end{tabular}

\section{2 載荷方法}

$400 \mathrm{tf}$ 万能試験機を用いて偏心軸方向圧縮力を与える 装置をFig.11(a)，（b）に示す。装置（a）は，偏心距 離 $25 \mathrm{~mm}, 50 \mathrm{~mm}$, 装置 (b) は, 偏心距離 $75 \mathrm{~mm}$, $100 \mathrm{~mm}$ の載荷試験に用いている。また， $100 \mathrm{~mm}$ を超 える偏心距離の載荷試験の場合には, Fig. 11(c) に示 すように，一定軸方向圧縮力の下で，ベースプレート下 面から $1000 \mathrm{~mm}$ の高さの位置に水平力を与える装置を 用いている。

CE 1 CE 4 は偏心圧縮力を受ける試験体であり, 偏 心距離 $\mathrm{e}$ はいずれも $100 \mathrm{~mm}$ に設定されている。 $\sim \mathrm{CE} 8\},\{\mathrm{CE} 10 \sim \mathrm{CE} 13\},\{\mathrm{CE} 15 \sim \mathrm{CE} 18\},\{\mathrm{CE} 20$ $\sim$ CE 23\}, \{CE 25 CE 28\}, \{CE 30〜CE 33\} は, 偏 心圧縮力を受ける試験体であり, 偏心距離を中括弧内に 示された試験体の順に，それぞれ，25 mm，50 mm，75 $\mathrm{mm}, 100 \mathrm{~mm}$ に設定している。また，CE9，CE 14, CE 19, CE 24, CE 29, CE 34 は, ベースプレート下 面から高さ $h=1000 \mathrm{~mm}$ の位置に，水平力を受ける試 験体であり，軸方向圧縮力 ${ }_{E} N$ を，それぞれの順に，55 $\mathrm{tf}, 70 \mathrm{tf}, 50 \mathrm{tf}, 50 \mathrm{tf}, 40 \mathrm{tf}, 50 \mathrm{tf}$ に設定している。なお, 試験体のベースプレート下面には，厚さ $10 \mathrm{~mm}$ 程度の 高強度無収縮モルタルが充填されており, モルタルの圧 縮強度が $450 \mathrm{kgf} / \mathrm{cm}^{2}$ 程度に達していることを確認した 後，載荷試験を開始している。

\section{3 実験結果}

\subsection{1 破壊状況}

一例として, 偏心距離 $75 \mathrm{~mm}$ の偏心圧縮力を受け, ベースプレート厚が $50 \mathrm{~mm}, 36 \mathrm{~mm}, 25 \mathrm{~mm}$ で, 基礎 コンクリートの高さが $400 \mathrm{~mm}, 200 \mathrm{~mm}$ の試験体の破 壊状況をFig. 12(a)～(f) に示す。支圧ひび割れは, ベー スプレート厚が小さくなるにつれて圧縮側ベースプレー 卜最外縁から圧縮側柱フランジのほうに移行する傾向を 示す。なお，基礎の高さ変化による破壞性状の差異は特 に見られない。

\subsection{2 曲げモーメントと軸力の相関式}

本実験のように鋼柱が箱形断面, ベースプレートの底 面および基礎コンクリートの断面が長方形の場合には, ベースプレートが薄くなると，その有効面積は，Fig.7 （a）に示すような中空の箱形になると考えられ，基礎コ ンクリートの曲げモーメント $M$ と軸力 $N$ の相関式 $(M-N$ 相関式) は複雑化し, 実用的ではない。したがっ て本研究では, 計算の単純化を図るために, 箱形の面積 を等価な長方形の面積に置換し，新たに支圧面積として (11）式で表されるようなベースプレートの有効面積 ${ }_{8} A_{e}$ を想定する。

$$
{ }_{B} A_{e}={ }_{B} B_{e} \cdot{ }_{B} D_{e}
$$

ここで

$$
\begin{aligned}
& { }_{B} B_{e}={ }_{B} B_{O}-{ }_{B} D_{I} \cdot{ }_{B} B_{I} /{ }_{B} D_{O} \\
& { }_{B} D_{e}={ }_{B} D_{O} \\
& { }_{B} B_{O}={ }_{C} B+2{ }_{B} t \cdot \cot \theta+2 S \\
& { }_{B} D_{O}={ }_{C} D+2{ }_{B} t \cdot \cot \theta+2 S \\
& { }_{B} B_{I}={ }_{C} B-2_{B} t \cdot \cot \theta-2_{c} t \\
& { }_{B} D_{I}={ }_{C} D-2_{B} t \cdot \cot \theta-2 t \\
& 0 \varliminf_{B} B_{I}<{ }_{B} B_{0} \leqq_{B} B \\
& 0 \varliminf_{B} D_{I}<{ }_{B} D_{O}{ }_{B} D
\end{aligned}
$$

${ }_{c} B,{ }_{c} D,{ }_{c} t:$ 鋼柱断面の幅，せい，板厚

${ }_{B} B,{ }_{B} D,{ }_{B} t:$ :゙ースプレートの幅, せい, 板厚

${ }_{B} B_{e},{ }_{B} D_{e}:$ ベースプレートの有効幅, 有効せい $S:$ 鋼柱表面からベースプレート上の溶 


\section{接止端部までの距離}

曲げモーメントと軸力を受ける基礎コンクリートの ベースプレート位置における力の釣合いの代表例を Fig. 13 に示す。基礎コンクリートを，上記の有効面積 ${ }_{B} A_{e}$ を断面とする無筋コンクリートの柱と見なし，長方 形， 2 次のパラボラ，三角形の 3 種類のコンクリートの 支圧反力分布を想定すると, 基礎コンクリートの $M-N$ 相関式は，それぞれ，(12)～(16) 式のように表される。 なお，この有効面積を用いて得られる $M-N$ 相関式は， 箱形の面積を用いる場合に比べて，明らかに安全側に基 礎コンクリートの終局曲げ耐力を予測可能である。

1）支生反力分布を長方形とする場合

$$
M=1 / 2 \cdot N \cdot{ }_{B} D_{e}\left\{1-N /\left({ }_{B} B_{e} \cdot{ }_{B} D_{e} \cdot F_{b}\right)\right\} \cdot
$$

2）支压反力分布を 2 次のパラボラとする場合

a) $N \leqq 2 / 3 \cdot{ }_{B} B_{e} \cdot{ }_{B} D_{e} \cdot F_{b}$ のとき

$$
M=1 / 16 \cdot N \cdot{ }_{B} D_{e}\left\{8-9 \cdot N /\left({ }_{B} B_{e} \cdot{ }_{B} D_{e} \cdot F_{b}\right\}\right\}
$$

b) $N>2 / 3 \cdot{ }_{B} B_{e} \cdot{ }_{B} D_{e} \cdot F_{b}$ のとき

$$
M=1 / 4 \cdot{ }_{B} B_{e} \cdot{ }_{B} D_{e}^{2} \cdot F_{b}\left\{1-N /\left({ }_{B} B_{e} \cdot{ }_{B} D_{e} \cdot F_{b}\right)\right\}
$$

3）支圧反力分布を三角形とする場合

$$
\text { a) } \begin{aligned}
& N \leqq 1 / 2 \cdot{ }_{B} B_{e} \cdot{ }_{B} D_{e} \cdot F_{b} \text { のとき } \\
& \left.M=1 / 6 \cdot N \cdot{ }_{B} D_{e}\left\{3-4 \cdot N /{ }_{B} B_{e} \cdot{ }_{B} D_{e} \cdot F_{b}\right)\right\} \cdots \\
\text { b) } \quad & N>1 / 2 \cdot{ }_{B} B_{e} \cdot{ }_{B} D_{e} \cdot F_{b} \text { のとき } \\
& M=1 / 6 \cdot{ }_{B} B_{e} \cdot{ }_{B} D_{e}^{2} \cdot F_{b}\left\{1-N /\left({ }_{B} B_{e} \cdot{ }_{B} D_{e} \cdot F_{b}\right)\right\}
\end{aligned}
$$

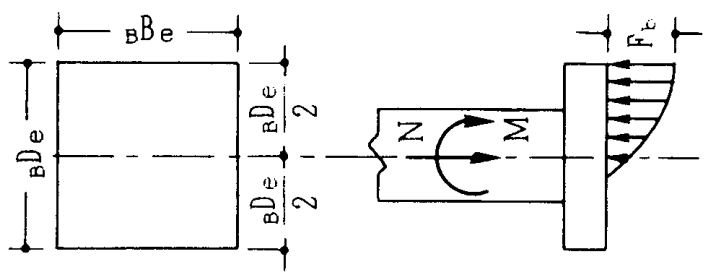

Fig. 13 Typical load carrying mechanism

\subsection{3 奏験結果の考察}

基礎コンクリートの偏心圧縮試験および一定軸力下に おける水平加力試験から得られた最大耐力を Table 4 に 示す。

実験值之（6）式の支圧強度”を用いて得られる基礎 コンクリートの $M-N$ 相関曲線との比較結果を, ベース プレートのサイズにより，試験体 CE 1 C CE 4, CE 5 〜CE 14, CE 15 CE 24, CE 25 CE 34 の 4 グルー プに分けて Fig. 14(a)〜 (d) に示す。また, 夷験値と（8) 式および（10）式を用いて得られる $M-N$ 相関曲線の比 較結果をFig. 15(a)〜(d) およびFig. 16(a)〜(d) に 示す。なお，基礎コンクリートの高さ ${ }_{F} h$ は, $400 \mathrm{~mm}$, $300 \mathrm{~mm}, 200 \mathrm{~mm}, 100 \mathrm{~mm}$ の 4 種類であり, 実験优を, それぞれの順に， $, \diamond, \triangle, \nabla$ 記号で示す。一方，ベー スプレートのサイズおよび基礎コンクリートの高さによ

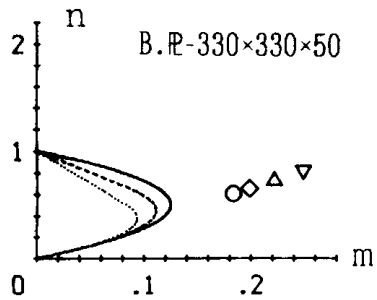

(a) $\mathrm{CE} 1 \sim \mathrm{CE} 4$

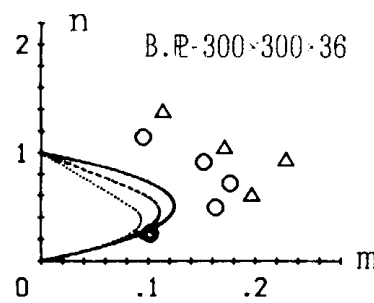

(c) $\mathrm{CE} 15 \sim \mathrm{CE} 24$

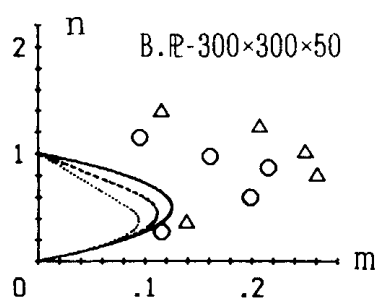

(b) CE5 CE14

(d) $\quad$ CE2 $25 \sim \mathrm{CE} 34$

$\bigcirc: F h=400, \diamond: F h=300, \triangle: F h=200, \nabla: F h=100$

- Rectangle, ..-Parabola, ..... Triangle

Fig. $14 m$ - $n$ interacion curves for footings (using Eq. (6), and grouping by geometric properties of base plates)

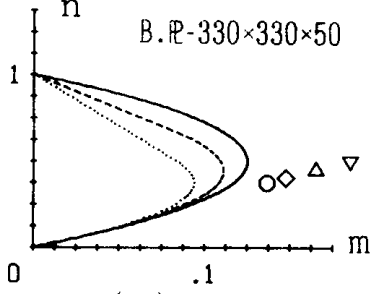

(a) CE1 CE4

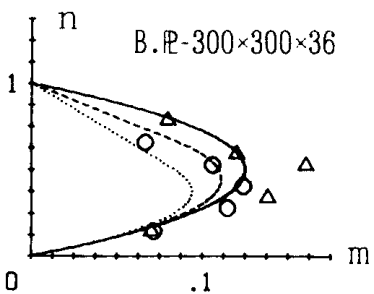

(c) CE15 CE24

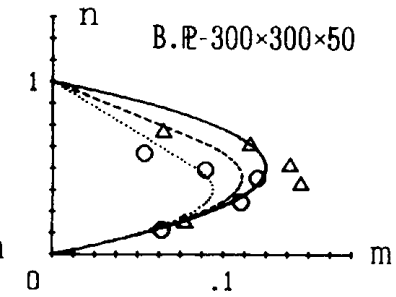

(b) CE5 CE14
$0 \cdot \mathrm{h}=400 \sim \mathrm{P} \cdot \mathrm{h}=300, \Delta \cdot \mathrm{h}=200, \nabla: \mathrm{h}=100$

--Rectangle, -.-Parabola, ..... Triangle

Fig. $15 m-n$ interaction curves for footings (using Eq. (8), and grouping by geometric properties of base plates)

り実験值を区別せず，実験值と（6)，(8)，(10) 式の 支压強度を用いて得られる $M-N$ 相関曲線とのマクロ的 な比較結果を，それぞれの順に，Fig. 17(a)〜 (c) に示 す。なお，この場合には，すべての奏験值を○叞号で示 す。

支玨反力分布を長方形，2次のパラボラ，觢形の 3 種類に想定して得られる $M-N$ 相関曲線（以下の考察で は，長方形 $M-N, 2$ 次のパラボラ $M-N$, 兰角形 $M-N$ 亡略記する）を，それぞれの順に，実線，破線，点線で Fig. 14〜Fig. 17 に示す。なお，支王強度の䂆测に（6） ，(8)，(10)式を用いる場合には,(11)式のベースプレー 卜の有効面積の計算において，それぞれの順に， $\theta=0^{\circ}$, $\theta=45^{\circ}, \theta=32.6^{\circ}$ とし，浴接の補強盛りの大きさ $S$ を

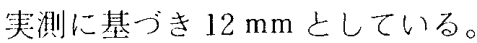


また，Fig.14〜Fig.17の縦軸および横軸は，(17） および（18）式のように無次元化軸力 $n$ および無次元 化モーメント $m$ を表している。

$$
\begin{aligned}
& n=N /\left({ }_{B} B_{e}{ }_{B} D_{e} \cdot F_{b}\right) . \\
& m=M /\left({ }_{B} B_{e} \cdot{ }_{B} D_{e}^{2} \cdot F_{b}\right)
\end{aligned}
$$

支圧強度の予測に（6）式を用いた場合の $M-N$ 相関 曲線之実験值の比較 (Fig. 14(a) （d)) から，ベースプ レートの強度・剛性および基礎コンクリートの高さの変 化に対して，(6) 式ではほとんど対応できないことが 分かる。計算による最大圧縮耐力の $1 / 2$ 以下の軸力では, 長方形 $M-N$ は実験值を良く追跡している。それより大 きな軸力では, 長方形 $M-N$ はベースプレートの強度・ 剛性が最も小さな試験体 CE 25 CE 34 の実験值をお おむ极追跡しているが，ベースプレートの強度・剛性が 大きくなるにつれて，また基礎の高さが小さくなるにつ れてかなり安全側に実験值を評価している。なお，本実 験におけるすべての試験体の耐力は，長方形 $M-N$ 上り 大きな值を示しており，2 次のパラボラ $M-N$ および三 角形 $M-N$ との比較結果については特に言及しない。

支圧強度の予測に（8）式を用いた場合の $M-N$ 相関 曲線と実験值の比較（Fig. 15(a)～(d)) から, ベース

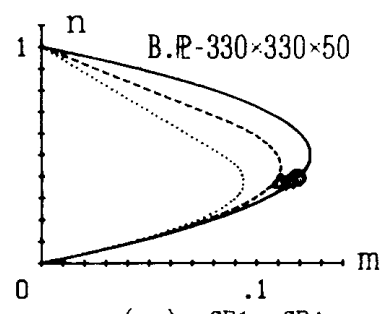

(a) $\mathrm{CE} 1 \sim \mathrm{CE} 4$

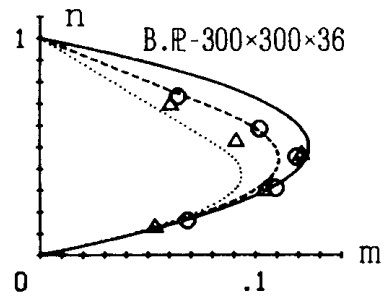

(c) CE15 CE24

$O: F h=400, \diamond: F h=300, \triangle: F h=200, \nabla: F h=100$

- Rectangle, ..- Parabola, ..... Triangle

Fig. $16 m^{-n}$ interaction curves for footings (using Eq. (10), and grouping by geometric properties of base plates)
プレートの強度・剛性による差異はほとんど見られない が，基礎コンクリートの高さの変化による差異はかなり 大きいことが分かる。計算による最大圧縮耐力の $1 / 2$ 以 下の軸力では, 三角形 $M-N$ はかなり安全側に，2次の パラボラ $M-N$ は若干安全側に実験値を評価しており, 長方形 $M-N$ は良く実験值を追跡している。それより大 きな軸力では，実験值は特定の相関曲線では追跡できす， 三角形 $M-N$ に近いもの，長方形 $M-N$ に近いもの，2 次のパラボラ $M-N$ に近いものとに分かれている。

支圧強度の予測に（10）式を用いた場合の $M-N$ 相関 曲線と実験值の比較（Fig. 16(a)～(d)) から，ベース プレートの強度・剛性並びに基礎コンクリートの高さの 変化による差異はほとんど見られないことが分かる。計 算に上る最大压縮耐力の $1 / 2$ 以下の軸力では，三角形 $M-N$ はかなり安全側に，2次のパラボラ $M-N$ は若干 安全側に実験值を評価しており，長方形 $M-N$ は極めて 良く実験值を追跡している。それより大きな軸力では， 三角形 $M-N$ は若干安全側に, 長方形 $M-N$ は若干危険 側に実験值を評価しており，2次のパラボラ $M-N$ は良 く実験值を追跡している。

また，Fig. 17(a)〜(c) には，縦軸・横軸のスケール を統一して実験值を示しており，明らかに，(6) 式よ りは（8）式を，（8）式よりは（10）式を露出形式柱 脚基礎コンクリートの支圧強度の予測式として用いた場 合が実験储を良く追跡できることが分かる。本実験から， 支圧強度の実験式としてベースプレートの強度・㴊性並 びに基礎コンクリートの高さ径比を考慮した（10）式を 用いることが最も妥当であることが検証された。なお， 文献 7）に提示されている支圧強度（6）式を用いた場 合の $M-N$ 相関曲線は，中心圧縮試験結果と同様に，偏 心圧縮試験および一定軸力下での水平加力試験結果にお いても本実験の下限值に近い值を示すことがうかがえ る。

以上に示した実験値と $M-N$ 相関曲線の比較検討結果 から，支圧強度の予測に（10）式を用い，支圧反力分布 に 2 次のパラボラを用いて得られる $M-N$ 相関曲線は, 計算による軸力の全範囲において，実験值を最も良く追 跡していることが分かる。また，支圧強度の予測に (10)

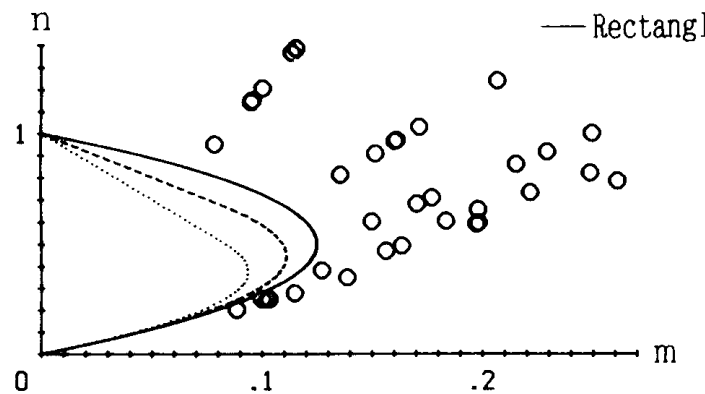

(a) Using Eq.(6)

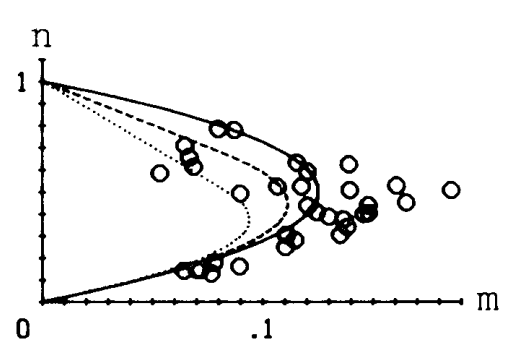

(b) Using Eq. (8) ...... Triangle, $\quad$ : Test result

Fig. $17 m-n$ interaction curves for footings (plotting all data)

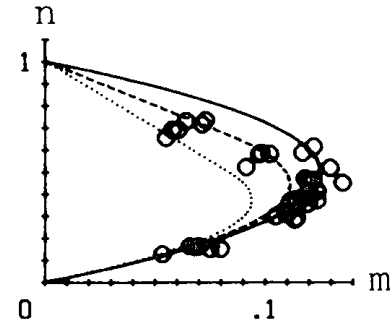

(c) Using Eq. (10) 
式を用い，支环反力分布に長方形を用いて得られる $M-N$ 相関式は，計算による最大圧縮耐力の $1 / 2$ の軸力 以下では，実験值を極めて良く追跡しており，適用限界 軸力を設定することにより露出形式柱脚の基礎コンク リートの終局曲げ耐力を最も簡明に予測可能である。

\section{4. 結 び}

露出形式柱脚の基礎コンクリートの中心王縮試験, 偏 心圧縮試験および一定軸軸力下での水平加力試験を行っ た結果からつぎのような結論が得られた。

（1）ベースプレートの強度・剛性および基礎コンク リートの高さ径比を考慮した露出形式柱脚の基礎コンク リートの支圧強度の実験式として（10）式を得た。なお， 中柱のように曲げを受ける構面内に基礎ばりを有する場 合には，基礎ばり天端からの立上がり部の高さを基礎の 高さと見なすことができる。

（2）基礎コンクリートの終局曲げ耐力は，(10）式の 支玨強度を用い, 支王反力分布を 2 次のパラボラとし, ベースプレートの有効面積を断面とする無筋コンクリー トの柱と見なして求めることができる。また，支圧反力 分布を長方形とする場合には, 最大生縮耐力の $1 / 2$ を超 える軸力では，実験耐力を若干危険側に評価する傾向が ある。

（3）文献 7）の支圧強度を用いると, 基礎コンクリー トの終局曲げ耐力は, ベースプレートの強度・剛性が大 きくなり，基礎コンクリートの形状が相対的に偏平にな るにつれて実験耐力をかなり安全側に評価する傾向があ る。

\section{参考文献}

1）日本建築学会：鉄筋コンクリート終局強度設計に関する 資料 23, 24, pp. 90 100, 1987

2）秋山 宏, 黒沢 稔, 和国信之, 西村 功：鋼構造露出
柱脚の強度と変形, 日本建築学会論文報告集, 第 342 号, pp. $46 \sim 54,1984.8$

3）加藤 勉, 佐藤邦昭, 鈴木周衛, 遠山幸三, 中村嘉宏, 坂本光雄：鋳鋼製柱脚金物 HIBASE を用いた露出型柱 脚の研究 (その 4 ：立上がり基礎部の支圧強度), 日本建 築学会大会学術講演梗概集, pp. 1221 1222, 1984

4）若林 実, 南 宏一, 西村泰志: 鉄骨鉄筋コンクリート 構造柱脚部のベースプレートの応力伝達機構, 構造工学 論文集, Vol. 32 B, pp. 147 158, 1986.3

5) 岡田 清, 六車 熙: コンクリート工学ハンドブック, 朝倉書店，1981

6) 佐治泰次：建築材料, コロナ社, 1984

7) 日本建築学会：鋼管構造設計施工指針・同解説, 1990

8) A. Williams: The bearing capacity of concrete loaded over a limited Area, Cement and Concrete Association, Technical Report 526, 1979

9）增田貫志, 九谷和秀, 河添隆司：鉄骨柱脚部の力学性状 に関する実験的研究, 露出形式柱脚の降伏耐力について （その1), 日本建築学会九州支部研究報告集, 第 29 号, pp. $329 \sim 332,1986$

10）増田貫志, 九谷和秀, 河添隆司 : 鉄骨柱脚部の力学性状 に関する実験的研究, 露出形式柱脚の降伏耐力について (その2), 日本建築学会大会学術講演梗概集 C 構造 II, pp. 883 884, 1986

11）増田貫志，九谷和秀, 河添隆司：鉄骨柱脚部の力学性状 に関する実験的研究，露出形式柱脚の降伏耐力について (その 3), 日本建築学会大会学術講演梗概集 C 構造 II, pp. 885 886, 1986

12）増田貫志，九谷和秀：鉄骨柱脚部の力学性状に関する実 験的研究, 露出形式柱脚の降伏耐力について（その 4), 日本建築学会大会学術講演梗概集 C 構造 II, pp. 1073 1074, 1987

13）増田貫志, 九谷和秀, 吉田祐輔：鉄骨柱脚部の力学性状 に関する実験的研究, 露出形式柱脚の降伏耐力について (その 7), 日本建築学会大会学術講演梗概集 C 構造 II, pp. 1365 1366, 1990

(1991 年 3 月 10 日原稿受理, 1991 年 7 月 5 日採用決定) 